\title{
Recurrent Blandin-Nuhn mucocele and intralesional ethanol injection
}

\author{
Tekrarlayan Blandin-Nuhn mukoseli ve lezyon içine etanol enjeksiyonu
}

\author{
İdris Çıldır (i)
}

Department of Otolaryngology, Private Selçuklu Hospital, Konya, Turkey

\begin{abstract}
A 21-year-old female patient presented with a swelling under the tongue that lasted about a month. A $2 \times 1 \mathrm{~cm}$ cystic lesion was found on the left side of the tongue ventral face in the physical examination, and the patient was operated. However, a partial recurrence was detected after the surgery; thereby, intralesional ethanol was administered. The lesion disappeared after the administration of ethanol, and there was no recurrence during the one-year follow-up. We presented this case to demonstrate the efficacy of this treatment method.
\end{abstract}

Keywords: Blandin-Nuhn, minor salivary gland, mucocele.

There are two types of salivary glands in the human body, major and minor, and the ducts of these glands open into the mouth. The fluids secreted from the glands are poured into the mouth through these channels and play an important role in chewing food, oral hygiene, and swallowing functions. Our tongue contains three different small clusters of salivary glands. These are von Ebner, Weber and Blandin-Nuhn glands. Anterior lingual glands, called Blandin-Nuhn, are located close to the apex in the midline and superficially on the ventral side of the tongue. It is not a single gland but consists of multiple clusters. They have serum-like secretions and open on both sides of the frenulum. Von Ebner and Weber glands are located in the dorsum and open to the root of the tongue. It has secretions of serous
$\ddot{O} Z$

Yirmi bir yaşında kadın hasta yaklaşık bir aydır süren dil altında şişlik şikayeti ile kliniğimize başvurdu. Hastanın fizik muayenesinde dil ventral yüzünün sol tarafında $2 \times 1 \mathrm{~cm}$ 'lik kistik lezyon saptandı ve hasta ameliyat edildi. Ancak ameliyat sonrası partial nüks görüldü, bunun üzerine lezyon içine etanol uygulandı. Etanol uygulaması sonrası lezyonun tamamen kaybolduğu ve bir yıllık takip sonunda nüks olmadığı tespit edildi. Bu tedavi yönteminin etkinliğinin araştırılmsı için nadir olguyu sunmayı uygun bulduk.

Anabtar sözcükler: Blandin-Nuhn, minör tükürük bezi, mukosel.

and mucous character. Mucoceles belonging to these two glands are rarely seen. ${ }^{[1]}$

Cystic lesions occur as a result of obstruction of salivary ducts for any reason. Since mucus accumulates in these cysts surrounded by a weak cell wall, they are called mucoceles. They are also classified histologically as retention or extravasation cysts. Extravasation cysts occur when mucus comes out of the canal due to trauma and are surrounded by connective tissue. Most salivary mucoceles are of this type. ${ }^{[2]}$ They are frequently seen in young populations and the lower lip. Conversely, retention cysts are more common in the elderly, and the epithelial tissue forms the cyst wall. It is assumed that mucin plugs are formed by occluding the salivary

Received: June 21, 2021 Accepted: September 05, 2021 Published online: November 11, 2021

Correspondence: İdris Çıldır, MD. Medicana Konya Hastanesi Kulak Burun Boğaz Bölümü, 42060 Selçuklu, Konya, Türkiye. e-mail: idriscildir@hotmail.com 
duct. $^{[2,3]}$ Average dimensions vary between $2-20 \mathrm{~mm}$. When viewed grossly, they are classified as small lesions between 2-9 mm, as medium lesions between 10-19 mm, and as large lesions when $20 \mathrm{~mm}$ and above. It is easily diagnosed by physical examination, and no radiological or biochemical tests are required. Its treatment is surgical removal of the lesion or marsupialization.

\section{CASE REPORT}

A 21-year-old female patient presented with a swelling under the tongue that lasted about a month. In the physical examination of the patient, who did not describe a history of trauma or a similar condition in the anamnesis, a $2 \times 1 \mathrm{~cm}$ cystic lesion was found on the left side of the tongue ventral face (Figure 1). No radiological or biochemical examinations were requested. Following the preoperative preparations, the patient's consent was obtained, and she was operated under local anesthesia one week later. With the pre-diagnosis of mucocele, the cyst was opened through the marsupialization technique. The fluid inside was aspirated., and the wound lips were sutured outward. The inside of the cyst was washed with povidone-iodine solution, and antibiotic rapier (gauze pad) was placed in it. After five days of oral antibiotic treatment, the rapier was removed. Partial recurrence was detected at the operation site in the postoperative first month of the patient, who was followed up weekly (Figure 2).

Intralesional ethanol injection was planned, and informed consent was obtained from the patient. We injected 2-3 $\mathrm{mL}$ of pure ethanol into the lesion once a week. It was observed that the lesion regressed after the second dose and disappeared at the end of the first month. There was no recurrence after monthly follow-up for a year (Figure 3).

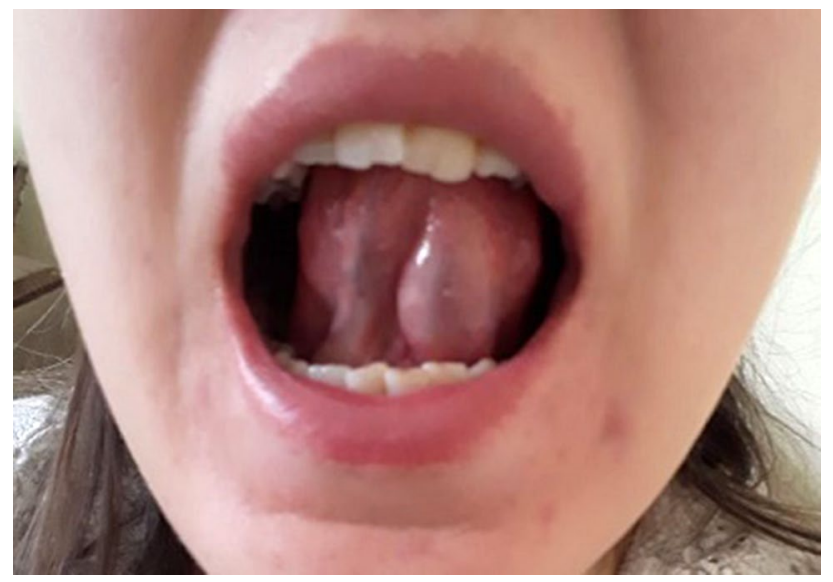

Figure 1. Image of the lesion.

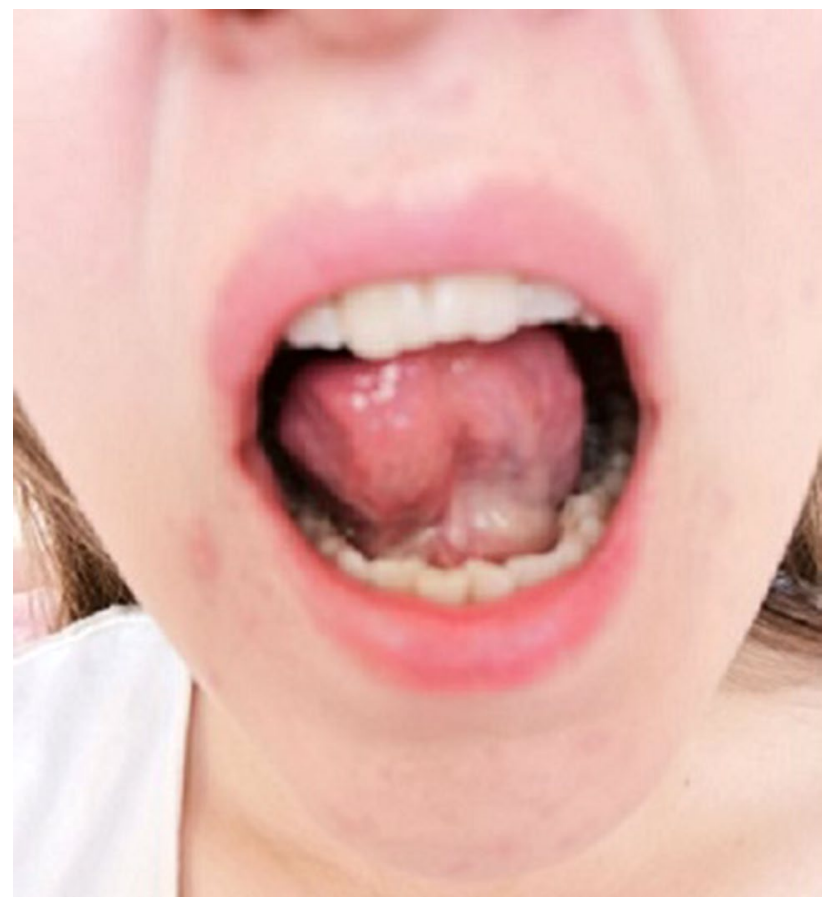

Figure 2. Recurrence is seen after surgery.

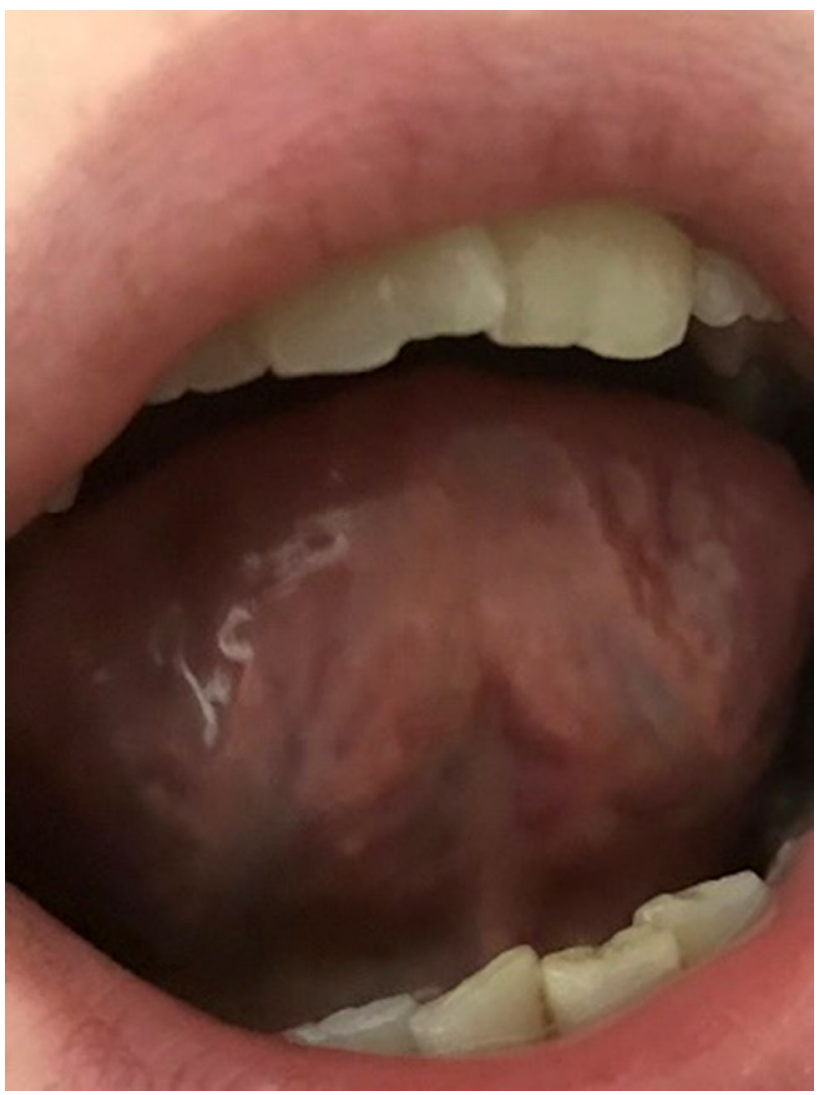

Figure 3. First year appearance after intralesional ethanol injection. 


\section{DISCUSSION}

Oral mucoceles are cystic lesions that are more common in asymptomatic females and children, usually with smooth borders. Its incidence is between $3.1 \%$ and $5.3 \% .{ }^{[4]}$ Cystic structures are formed as a result of the blockage of Blandin-Nuhn glands due to various reasons. Mucoceles arising from these structures are extremely rare. This disease was first described in his sister by Heimansohn in $1970 .^{[5]}$ Jinbo et al. and Nico et al. reported that they detected Blandin-Nuhn mucoceles in $9.9 \%$ and $8.3 \%$ of their mucocele series, respectively. ${ }^{[5]}$ They are frequently seen after trauma and in asymptomatic young females. When they reach large sizes, the patient may have difficulty speaking and chewing. Its average dimensions vary between $2-20 \mathrm{~mm} \cdot{ }^{[6]}$ In our case, there was a 21 -year-old young female with a $20 \times 10 \mathrm{~mm}$ cyst in accordance with the literature. History and physical examination are the most important diagnostic criteria in its diagnosis. ${ }^{[7]}$ Radiological and biochemical examinations are not required for diagnostic purposes. Pyogenic granulomas, polyp, squamous papilloma, and lymphangioma should be ruled out in the differential diagnosis. ${ }^{[5]}$

The primary and traditional treatment method is a surgical approach, which varies according to the location and size of the cyst. Baurmash et al. ${ }^{[8]}$ mention three types of approaches: small mucoceles should be completely removed, medium-sized mucoceles should be removed with the minor saliva glands around them, and in large mucoceles, marsupialization is preferred. ${ }^{[8]}$

Marsupialization can be defined as emptying the inside of the cyst and turning the wound lips outwards, stitching them to the neighboring tissues. In this way, the cyst wall is atrophied, and the cyst gradually disappears. This method is preferred in large cysts since completely removing the cyst will create a defect in the surgical area. Although we used this method in our case, we observed a recurrence on the $15^{\text {th }}$ day.

Since the mucoceles have a very thin capsule, the mucin inside often bursts during surgical dissection, making the surgery difficult. To avoid such situations, some authors have argued that the lesion can be removed by injecting chemicals that can occupy volume into the cyst. ${ }^{[8,9]}$ They applied it in larger lesions such as ranula and achieved successful results. However, there are authors who do not recommend this method. ${ }^{[10]}$ According to them, these rubber-like chemicals cause foreign body reactions in the tissue.

Cryosurgery laser ablation and intralesional steroid injection have been recommended as an alternative to surgical treatment in small lesions.[8] Absolute ethanol injection is used as a sclerosing agent, particularly in cystic lesions, and successful results are obtained. Zhang and Wang ${ }^{[10]}$ administered a dose of intralesional ethanol to ventrally located tongue mucocele cases and achieved successful results. We also administered 1-2 $\mathrm{mL}$ intralesional ethanol injection once a week to this patient who had relapses. We saw that the lesion completely disappeared after the second dose. We did not detect any recurrence during the one-year follow-up.

As a result, it is possible to argue that intralesional alcohol injection can be an inexpensive and effective treatment method without complications. It would be appropriate to conduct a larger study on this subject.

\section{Declaration of conflicting interests}

The author declared no conflicts of interest with respect to the authorship and/or publication of this article.

\section{Funding}

The author received no financial support for the research and/or authorship of this article.

\section{REFERENCES}

1. Sugerman PB, Savage NW, Young WG. Mucocele of the anterior lingual salivary glands (glands of Blandin and Nuhn): Report of 5 cases. Oral Surg Oral Med Oral Pathol Oral Radiol Endod 2000;90:478-82.

2. Harrison JD. Salivary mucoceles. Oral Surg Oral Med Oral Pathol 1975;39:268-78.

3. Andiran N, Sarikayalar F, Unal OF, Baydar DE, Ozaydin E. Mucocele of the anterior lingual salivary glands: From extravasation to an alarming mass with a benign course. Int J Pediatr Otorhinolaryngol 2001;61:143-7.

4. Brooks JK, Schwartz KG, Basile JR. Superficial Mucocele of the Ventral Tongue: Presentation of a Rare Case and Literature Review. J Oral Maxillofac Surg 2016;74:1175-9.

5. Banu V, Kishor Kanneppady S, Anusha RL. Mucocele of the glands of Blandin-Nuhn. SADJ 2013;3:26-9.

6. Thomas S, Velayudhannair V, Thomas J, Lekha SB. A clinicopathologic discussion on a case of asymptomatic swelling on the ventral tongue. Saudi J Health Sci 2019;8:191-3.

7. Kumaresan R, Karthikeyan P, Mohammed F, Thapasum Fairozekhan A. A novel technique for the management of blandin-nuhn mucocele: A case report. Int J Clin Pediatr Dent 2013;6:201-4.

8. Rai AJ, Hegde AM, Shetty YR. Management of BlandinNuhn mucocele--a case report. J Clin Pediatr Dent 2008;32:147-9.

9. Ellis E 3rd, Scott R, Upton LG. An unusual complication after excision of a recurrent mucocele of the anterior lingual gland. Oral Surg Oral Med Oral Pathol 1983;56:467-71.

10. Zhang J, Wang C. The Application of absolute ethanol in the treatment of mucocele of the glands of Blandin-Nuhn. J Craniofac Surg 2016;27:e641-e642. 